\title{
State Salinity Strategy biological survey of the Western Australian wheatbelt: background
}

\author{
G.J. Keighery \\ Department of Conservation and Land Management, Science Division, \\ P.O. Box 51 Wanneroo, Western Australia 6946, Australia
}

\section{INTRODUCTION}

Dryland salinity was first recognised as a significant threat to agriculture in the Western Australian wheatbelt in the early twentieth century (Mann, 1907; Patterson, 1917; Wood, 1924). However, it was not until the early 1970s that rising saline groundwaters were identified as a major threat to wetland biodiversity at Lake Toolibin (NARWC, 1987). The severity and widespread nature of the threat to biodiversity, both in Western Australia and elsewhere in Australia, received little attention in the scientific literature until the late 1980s when papers on wetland (Halse, 1988, Hart et al. 1990; Halse et al. 1993a,b) and terrestrial effects (George et al., 1995) were documented. Soon after a whole of Government approach was announced to combat dryland salinisation in Western Australia. Initially called the Salinity Action Plan (Government of Western Australia, 1996), through a process of review and public consultation it became the Western Australian Salinity Strategy (State Salinity Council, 2000).

During the development of the Salinity Action Plan it was recognised that the natural biodiversity of the south-west agricultural region was poorly documented. As a consequence, it was essential to survey the biological resources of the area to provide a basis for planning a systematic response to salinisation. Specifically, it was stated that (Government of Western Australia, 1996, page 24):

"Much better biological data are required to:

Select further recovery catchments, and provide ecological advice for catchment management;

Understand and develop the resource base of species for use in land conservation and for commercial development."

The accompanying Action Statement was:

"CALM will:

- Conduct a biological survey, in the agricultural region, with an emphasis on low-lying areas that are vulnerable to salinity, to identify nature conservation priorities and to identify plant species that are likely to be of value in revegetation for both commercial production and land conservation;
- Using the results of the biological survey and following discussions with peak advisory bodies and affected community groups, the Government will select an additional three or four key recovery catchments by the end of 2000;"

- Funding of $\$ 0.5$ million per year to be provided for CALM to undertake this work, commencing in late 1997."

Three Natural Diversity Recovery Catchments varying in size from 50,000 to 130,000 ha were nominated in the original Salinity Action Plan. They were centred on Toolibin Lake (east of Narrogin), the Lake Muir wetland complex (east of Manjimup) and the Lake Warden complex at Esperance.

Preliminary results from the survey have already been used:

- To identify a further three recovery catchments around Lake Bryde, (south of Lake Grace), between Buntine and Marchagee in the northern wheatbelt and around Drummond Nature Reserve (west of Bolgart).

- Incorporated in the 1998 Draft Plan update (State Salinity Council, 1998) and the subsequent Salinity Strategy (State Salinity Council, 2000).

- Provided to the review of the Strategy (Frost et al., 2001) and the Wallace (2001) review of CALM's role in salinity management.

The reviews led to some enhancement of the Biological Survey Program. These included the following actions. It was proposed that the results of the biological survey be combined with those of the SS2020 project to help define biodiversity conservation priorities (Salinity Strategy, 1998; page 31). This resulted from a report to the State Salinity Council by Clarke et al. (1999) dealing with the effect of recharge management on the extent of dryland salinity, flood risk and biodiversity in Western Australia. Subsequently these data were combined into a separate report to the State Salinity Council (George et al., 1999). The use of the Biological Survey Program to identify species that should, as a matter of priority, be collected for germplasm storage was also identified in the Salinity Strategy (page 32 and page 8 of the action 
statements). Lists of vascular plant species particularly at risk have been provided to CALM's Seed Storage Unit, and a detailed list is being prepared separately. Also, with the higher profile given to management of saline lands in the Salinity Strategy, the need for the Biological Survey Program to identify saline areas of high biodiversity for improved management was also noted.

A final change was that CALM would identify at least six more natural diversity recovery catchments by 2005 based on survey findings by 2003. A preliminary list of 24 potential recovery catchments was provided to the Salinity Council by CALM in 2001 (Keighery and Lyons, 2001).

Thus by 2000, the key recommendations within the Salinity Strategy (Salinity Actions, page 8) were:

- "Complete and publish the results of the biological survey of the agricultural region begun in 1997, with an emphasis on low-lying areas that are vulnerable to salinity, to identify nature conservation priorities and to identify plant species that are likely to be of value in revegetation for both commercial production and land conservation;

- Use the results of the biological survey and, following consultation with peak advisory bodies and affected community groups, progressively select additional recovery catchments and develop and implement recovery plans; and

- Conduct more detailed biological surveys needed at catchment and local scales."

To underpin management initiatives in the Salinity Action Plan and the State Salinity Strategy, the area covered by the biological survey was mostly between the 300 and $600 \mathrm{~mm}$ isohyets. This encompasses what is loosely referred to as the wheatbelt and the more eastern parts of the south coast. There was an emphasis on low-lying areas that are vulnerable to salinity. Specific aims of the survey are listed below:

(1) Document and assess patterns in species composition across the south-western agricultural zone using a wide range of organisms,

(2) Identify and prioritise potential recovery catchments (with respect to nature conservation values),

(3) Provide a regional perspective on nature conservation priorities to help determine and prioritise management actions, particularly in regard to salinity,

(4) Provide baseline data and a regional framework for future monitoring,

(5) In collaboration with appropriate groups/ individuals (a) draw up lists of plant species that are likely to be of value in revegetation for commercial production and/or land conservation and (b) use survey data and other corporate databases to provide advice on actual or likely areas of occurrence, and provide information for updating of REX (Revegetation manual), etc.

In order to have predictive value the survey needed to be site based, describing the physical and biological attributes of each sampling site. Previous approaches used to select areas of high conservation value in the agricultural zone have been nonquantitative; for example: using large-scale vegetation maps (Beard, 1990) or have been applied to limited areas. To support the Salinity Action Plan, there was a need for a data set that provided both a broad picture and site-based information to allow predictive modeling and interpolation into areas that have not been surveyed. This one to one link between the physical and biological data is essential to provide a basis for predicting the presence of species or species assemblages beyond the actual sampling points. In addition, a site based approach is essential to provide an explicit basis for monitoring.

\section{The study area - "The Wheatbelt"}

The specified study area as defined in the Salinity Action Plan extended from the $600 \mathrm{~mm}$ annual rainfall isohyet inland to the eastern edge of land clearing, an area of approximately 25 million hectares. The study area is central to temperate south-western Australia, an area that is recognized internationally as a mega diverse area for flowering plants. Significant parts (including virtually all of the Avon-Wheatbelt) of $\operatorname{six}^{1}$ of the eight biogeographic zones recognized in south-western Australia (Thackway and Creswell, 1995) are found in the wheatbelt. Thus the study area includes a high degree of biological diversity and biogeographical complexity.

However, the wheatbelt had no previous comprehensive systematic survey of the distribution and diversity of the biota of the region. Under the umbrella of the Salinity Action Plan, and subsequently the State Salinity Strategy, the CALM Biological Survey Group with Greg Keighery as Project Leader undertook a four-year field survey (1997-2000).

The survey was structured into three themes. The large number of knowledgeable and experienced specialists in each of these areas, from a variety of institutions allowed the survey to address the diversity of a wide variety of organisms at the species level. The themes and key participants are listed below:

\footnotetext{
1 These are the Geraldton Sandplains, Swan Coastal Plain, AvonWheatbelt, Jarrah Forest, Mallee and Esperance Sandplains zones.
} 
Terrestrial Communities

Flora: Greg Keighery, Neil Gibson and Andrew Webb (CALM).

Fauna: Vertebrates - Norm McKenzie, Allan Burbidge, Jim Rolfe and Bill Muir; Invertebrates (CALM) - Nadine Guthrie, Paul Van Heurck, Lisa King, Elisha Ladhams, Bethea Loudon and Bradley Durrant; Invertebrates (WA Museum) Julianne Waldock, Barabara York Main and Mark Harvey; and Frogs (University of Western Australia) - Dale Roberts.

Soils: Trevor Stoneman.

\section{Wetland Communities}

Flora: Mike Lyons and Simon Lyons (CALM)

Fauna: Stuart Halse, Dave Cale, Winston Kay, Jane McRae, Melita Pennifold, Adrian Pinder (CALM), Russell Shiel (University of Adelaide) and Dean Blinn (Northern Arizona University).

\section{SITE SELECTION AND SAMPLING}

The study area was divided into four zones for the purposes of the survey - a northern, central, southern and Dandarragan Plateau band.

Large bushland areas within the higher rainfall zone comprising State forest, the Swan Coastal Plain and other areas of the west and south coast were not covered by the survey as it was considered they were comparatively well documented by the Swan Coastal Plain Survey, work under the Regional Forests Agreement and the Warren Flora Study (Gibson et al., 1994, Gibson and Keighery, 2000 and Lyons et al., 2000). Many of these areas are not threatened by salinity.

\section{Terrestrial communities}

Flora

Overall approximately 700 terrestrial quadrats were established and scored, of which 304 were within the terrestrial fauna sites creating the terrestrial biodiversity sites. Additional sites were established to quantify variation observed on the geomorphic units. Another 130 quadrats were established by Mattiske and Associates and the botanical survey team in all vegetation types of six large reserves previously mapped structurally by Anne Coates to compare structure and floristics. Another 200 sites have been established as part of the community survey on private and local government lands. These sites will be reported on elsewhere.

\section{Fauna}

The 304 sampling sites were positioned on a minimally disturbed example of each of the 11 principal geomorphic units in the landscape, as well as on a salt-affected example of two of the units.
Uncleared sites were chosen on typical examples of each unit and preferably within a conservation reserve. Subsequently trapping systems were installed at the sites so ground-dwelling arachnids (spiders, scorpions, centipedes), some other invertebrates (carabid beetles and millipedes) and small vertebrates (mammals, reptiles and frogs) could be sampled.

\section{Soils}

Bulked surface soil samples from all terrestrial sites were collected for chemical analysis and the soil profile was described and sampled for chemical analysis. At each of the 304 biodiversity sites a description, sampling and chemical analysis of soil profiles was made. In conjunction with BIOCLIM data, these data allow modelling of species' "environmental envelopes", including their salinity responses.

\section{Wetland Communities}

\section{Flora and Fauna}

Two hundred and thirty-two wetlands were sampled for aquatic invertebrates, waterbirds and wetland associated plants (vascular plants growing in or around wetlands and macroalgae). Diatoms were sampled in about a third of the wetlands, with a bias towards saline sites (these results have been published separately, Blinn et al., 2004).

\section{Data Storage and analysis}

Data were entered into MS ACCESS databases. Generally presence-absence matrices for site by species were generated for analysis. Data analysis pathways are as discussed under each paper.

All sites were photographed and are archived on $\mathrm{CD}$ in selected libraries. A complete library of all soil samples is held at Woodvale.

\section{Outputs and activities}

The clear directive from the State Salinity Council was to share knowledge from the survey as quickly and widely as possible, some of these actions are outlined in the introduction.

Perhaps the most substantial output is the development and enhancement of participants' expertise. Members of the study have now seen most of the reserves of the agricultural zone and a significant amount of expert knowledge has accumulated on the region's biodiversity and the threats to its persistence.

Unlike most regional surveys there was a continual call for outcomes of the survey during its course. This resulted in participants being involved in the continual production of publications, reports, seminars and workshops during the progress of the survey. 
Reports included quarterly updates on progress of the survey provided to the State Salinity Council which were frequently used in their newsletter. Over 50 presentations at seminars and workshops were made during the survey to bodies as diverse as the National Biodiversity Lecture in Canberra, Greening Australia, Naturalist Clubs, CWA annual conference, CALM regions and districts and catchment groups, including an international conference on biodiversity effects of salination. Most of these presentations involved handouts of information and many of these have been published as proceedings or papers (Keighery, 2000, 2003, Keighery et al., 2000, 2001; Davis et al., 2003; Halse et al., 2003; McKenzie et al., 2003). There have also been a wide variety of popular articles ranging from newspapers, web pages, books, newsletters and natural history magazines (Keighery, 2001a,b).

Some natural diversity recovery catchments have been surveyed as requested in the Salinity Action Plan Review and subsequent State Salinity Strategy. A major publication on the vegetation and flora of the Lake Muir Natural Diversity Recovery Catchment has been published in CALMScience (Gibson and Keighery, 2000). The floral values of Drummond Nature Reserve (now a natural diversity recovery catchment) were documented and published (Keighery et al., 2002). The five year monitoring program for Lake Muir Recovery Catchment is in press (Gibson et al., 2004).

Aquatic invertebrate and waterbird species lists for some of the major wetlands in recovery catchments have been provided by Halse et al. (2000) and Cale et al. (2004).

There has also been a high level of community involvement ranging from field day, seminars and structured surveys For example approximately 200 sites established on private and shire lands by members of the Western Australian Wildflower Society (Inc.) supported by CALM. Detailed reports on the areas surveyed are placed in major libraries and a copy is held at Woodvale, eg: "Quairading Nature Reserve" (Keighery et. al., 2001). Woodland Watch was established by WWF to help with the conservation of Woodlands of the Western Wheatbelt as an outcome of the survey, this has also established a large number of floristic sites that will be used to detail floristic communities in these woodlands.

Taxonomic outcomes of the survey are also being published for the vascular flora (Keighery, 2002a,b,c, 2004a,b; Keighery and Marchant, 2002; Keighery and Keighery, 2004; Keighery and Lyons, $2004 a, b$ ) and wetland invertebrates (Watts and Pinder, 2000; Halse and McRae, 2001, 2004; Pinder and Halse, 2001).

This volume is another of the continuing outputs from the survey.

\section{ACKNOWLEDGEMENTS}

The State Salinity Council for interest in and support to the project and its continuance. The CALM regions (Swan, Mid West, Central Forest, Southern Forests and South Coast) and their districts where the survey was undertaken for assistance with site selection and logistics. CALM Information Management Branch for assistance provision of cadastral information to aid in site selection.

The numerous landholders, both State Local Government and private who facilitated access to study sites. The volunteers who assisted in sampling. Nicholas Hall for site establishment and databasing. Further details of these persons are included in the individual papers.

Funding for the survey was provided as a special allocation by the Government of Western Australia to the Department of Conservation and Land Management as part of the Salinity Action Plan and subsequently the State Salinity Strategy. Permanent staff and infrastructure were allocated to the survey from the Department of Conservation and Land Management and the Western Australian Museum; funding was used to employ additional staff on contract as well as cover operating costs.

\section{REFERENCES}

Beard, J.S. (1990). Plant life of Western Australia. Kangaroo Press, Sydney.

Blinn, D.W., Halse, S.A., Pinder, A.M., Shiel, R.J. and McRae, J.M. (2004). Diatom and zooplankton communities and environmental determinants in the Western Australia wheatbelt: a response to secondary salinization. Hydrobiologia 528: 229-248.

Cale, D.J., Halse, S.A. and Walker, C.D. (2004). Wetland monitoring in the wheatbelt of south-west Western Australia: site descriptions, waterbird, aquatic invertebrate and groundwater data. Conservation Science Western Australia 5: 20-135.

Clarke, C., George, R.J., Reggiani, P., and Hatton, T., (1999). The effect of recharge management on the timing and extent of dryland salinity in the Wheatbelt of Western Australia. Computer modelling study for State Salinity Council, Perth.

Frost, FM, Hamilton, B., Lloyd, M. and Pannell, D.J. (2001) Salinity: a new balance. Report of the taskforce established to review salinity management in Western Australia. Government of Western Australia, Perth.

George, R.J., McFarlane, D.J. and R.J. Speed (1995). The consequences of a changing hydrologic environment for native vegetation in southwestern Australia. In D.A. Saunders, J.L. Craig and E.M. Mattiske (eds), Nature conservation 4: the role of networks: 9-22. Surrey Beatty \& Sons, Sydney.

George, R.J., Clarke, C., Hatton, T., Reggiani, P., Herbert, A., Ruprecht, J., Bowman, S. and Keighery, G.J. (1999). The effect of recharge management on the extent of dryland salinity: Preliminary computer modelling study for State Salinity Council, Perth. 
Gibson, N., Keighery, B.J., Keighery, G.J., Burbidge, A.H. and Lyons, M.N. (1994). A floristic survey of the southern Swan Coastal Plain. Report prepared by the Western Australian Department of Conservation and Land Management and the Western Australian Conservation Council for the Australian Heritage Commission. Department of Conservation and Land Management, Perth.

Gibson, N. and Keighery, G.J. (2000). Flora and vegetation of the Byenup-Muir reserve system, southwest Western Australia. CALMScience 3: 323 - 402.

Government of Western Australia (1996). Western Australian salinity action plan. Government of Western Australia, Perth.

Halse, S.A. 1987. Probable effect of increased salinity on the waterbirds of Lake Toolibin. Technical Report 15. Department of Conservation and Land Management, Perth.

Halse, S.A. and McRae, J.M. (2001). Calamoecia trilobata n. sp. (Copepoda: Calanoida) from salt lakes in southwestern Australia. Journal of the Royal Society of Western Australia 84: 5-11.

Halse, S.A. and McRae, J.M. (2004). New genera and species of giant ostracods (Crustacea: Cyprididae) from Australia. Hydrobiologia 524: 1-52.

Halse, S.A., Pearson, G.B. and Patrick, S. (1993a). Vegetation of depth-gauged wetlands in nature reserves of south-west Western Australia. Technical Report 30. Department of Conservation and Land Management, Perth.

Halse, S.A., Pearson, G.B., McRae, J.M. and Shiel, R.J. (2000). Monitoring aquatic invertebrates and waterbirds at Toolibin and Walbyring lakes in the Western Australian wheatbelt. Journal of the Royal Society of Western Australia 83: 17-28.

Halse, S.A., Williams, M.R., Jaensch, R.P. and Lane, J.A.K. (1993b). Wetland characteristics and waterbird use of wetlands in south-western Australia. Wildlife Research 20, 103-126.

Halse, S.A., Ruprecht, J.K., and Pinder, A.M. (2003). Salinization and prospects for biodiversity in rivers and wetlands of south-west Western Australia. Australian Journal of Botany 51: 673-688.

Hart, B.T., Bailey, P., Hortle, K., James, K., McMahon, A., Meredith, C. and Swadling, K. (1991). A review of the salt sensitivity of the Australian freshwater biota. Hydrobiologia 210: 105-44.

Keighery, G.J. (2000a). Salinity: ? fifth horseman of the Apocalypse. Western Australian Wildflower Society Nevosletter 38 (4): 6-12.

Keighery, G.J. (2000b). Wheatbelt wonders under threat. Landscope 16: 37-42.

Keighery, G. (2001). State Salinity Strategy: CALM biological survey of the agricultural zone. In Salinity seminar: presented by the Midwest Oil Mallee Association, 21st August 2001, Morazoa Shire Hall: 1-10. Midwest Oil Mallee Association, Morawa.

Keighery, G.J. (2002). Taxonomic notes on the genus Stenopetalum (Brassicaceae). Nuytsia 14: 393-403.

Keighery, G.J. (2002b). Two new species of Comesperma (Polygalaceae) from Western Australia. Nuytsia 15: 53-58.

Keighery, G.J. (2002c). A new species of Conostephium
(Epacridaceae) from Western Australia. Nordic Journal of Botany 22: 49-52.

Keighery, G. (2003). Composition and conservation of the flora of the Western Australian agricultural zone. In Conference Papers: State Landcare Conference for Agricultural Sustainability, 7-10 October 2003, Katanning, Western Australia: 1-6. Conference Organising Committee, Katanning.

Keighery, G.J. (2004a). A taxonomic review of the Calytrix ecalycata complex (Myrtaceae). Nuytsia 15: 105-112.

Keighery, G.J. (2004b). A taxonomic review of the Angianthus drummondii (Asteraceae) species complex. Nuytsia 15: 97-104.

Keighery, G.J., Gibson, N., Webb, A. and Muir, W.P. (2002). A biological survey of the agricultural zone: vegetation and vascular flora of Drummond Nature Reserve. Conservation Science Western Australia 4: 63 78.

Keighery, G.J., Halse, S., McKenzie, N.L., Gibson, N., Burbidge, A.H. and Gomboso, J. (2000). Salinity: driving the catastrophic collapse of our ecosystem. Life Lines 6 (3): 29-30

Keighery, G., Halse, S. and McKenzie, N.L. (2001). Why wheatbelt valleys are valuable and vulnerable: the ecology of wheatbelt valleys and threats to their survival. In V.A. Read \& Associates (eds), Dealing with salinity in wheatbelt valleys: processes, prospects and practical options: 1-8. Water and Rivers Commission, Perth (Available on CD).

Keighery, G.J., Keighery, B.J., Gibson, N. and Gunness, A. (2001). Vegetation and flora of "Quairading Nature Reserve", Shire of Quairading. Western Australian Wildflower Society, Nedlands.

Keighery, G.J. and Keighery, B.J. (2004). Rediscovery of the genus Cymbonotus (Asteraceae) in Western Australia. Western Australian Wildflower Society Newsletter 42 (1): 25-26.

Keighery, G. and Lyons, M. (2001). Existing and potential natural diversity recovery catchments indicative list. Department of Conservation and Land Management, Western Australia, Perth.

Keighery, G.J. and Lyons, M.N. (2004a). A new species of Hypoxis (Hypoxidaceae) from Western Australia. Nutytsia 15 (in press).

Keighery, G.J. and Lyons, M.N. (2004b). A new species of Tribonanthes (Haemodoraceae) from Western Australia. Nuytsia 15 (in press).

Keighery, G.J. and Marchant, N.G. (2002). A new species of Darwinia (Myrtaceae) from Western Australia. Nordic Journal Botany 22: 45-48.

Lyons, M.N., Gibson, N. and Keighery, G.J. (2002). Wetland plant communities of the Western Australian agricultural zone: claypans, naturally saline wetlands and secondary salinity. In S.J. Bennett and M. Blacklow (eds), International Conference on Prospects for Biodiversity and Rivers in Salinising Landscapes: Albany, Western Australia, 20-27 October 2002: Conference Papers: 77-83. Centre of Excellence in Natural Resource Management, Albany.

McKenzie, N.L., Burbidge, A.H. and Rolfe, J.K. (2003). Effect of salinity on small, ground-dwelling animals in the Western Australian wheatbelt. Australian Journal of Botany 51: 1-16. 
Mann, A.W. (1983). Hydrochemistry and weathering on the Yilgarn Block, Western Australia - ferrolysis and heavy metals in continental brines. Geochimica et Cosmochimica Acta 47: 181-190.

NARWC. (1987). The status and future of Lake Toolibin as a wildlife reserve. Water Authority of Western Australia, Perth.

Paterson, J.W. (1917). Report on the occurrence of soluble salts in the lands of the Esperance district. Appendix 15. In Report of the Royal Commission on the mallee belt and Esperance lands: 165-193. Government of Western Australia, Perth.

Pinder, A.M. and Halse, S.A. (2001). Two new species of Ainudrilus (Clitellata: Tubificidae) from southwestern Australia, with notes on Ainudrilus nharna Pinder and Brinkhurst. Records of the Western Australian Museum 27: 1-7.

State Salinity Council. (1998). Western Australian Salinity Action Plan: draft update. Government of Western Australia, Perth.
State Salinity Council. (2000). Natural resource management in Western Australia: salinity. Western Australian State Salinity Strategy. Government of Western Australia, Perth.

Thackway, R. and Creswell, I.D. (eds) (1995). An interim biogeographic regionalisation for Australia: a frametwork for establishing the national system of reserves, version 4.0. Australian Nature Conservation Agency, Canberra.

Wallace, K.J. (2001). State Salinity Action Plan 1996: Review of the Department of Conservation and Land Management programs: January 1997-June 2000. Department of Conservation and Land Management, Perth.

Watts, C.H.S. and Pinder, A. (2000). Two new species of Antiporus Sharp from Western Australia (Coleoptera: Dytiscidae). Records of the South Australian Museum 33: 17-19.

Wood, W.E. (1924). Increase of salt in soil and streams following the destruction of native vegetation. Journal of the Royal Society of Western Australia 10: 35-47. 